\title{
An alternative synthesis of Azilsartan: an angiotensin II receptor blocker
}

\author{
Srinivas Garaga ${ }^{1,2^{*}}$, Nimesh C. Misra ${ }^{1}$, Ambati V. Raghava Reddy ${ }^{1}$, \\ Koilpillai Joseph PrabahaR ${ }^{1}$, Chandiran Takshinamoorthy ${ }^{1}$, \\ Paul Douglas Sanasi ${ }^{2}$, Raghubabu Korupolu ${ }^{2}$
}

\begin{abstract}
${ }^{1}$ Chemical Research and Development Department, Aurobindo Pharma Ltd, Survey No: 71\&72, Indrakaran Village, Sangareddy Mandal, Medak district, Hyderabad - 502329, Andhra Pradesh, India

${ }^{2}$ Department of Engineering Chemistry, A. U. College of Engineering (A), Andhra University, Visakhapatnam - 530003, Andhra Pradesh, India

\begin{tabular}{|c|c|}
\hline ARTICLE INFO & ABSTRACT \\
\hline $\begin{array}{l}\text { Received } 14 \text { November } 2014 \\
\text { Accepted } 27 \text { March } 2015\end{array}$ & \multirow{2}{*}{$\begin{array}{l}\text { This paper provides a description of an alternative, novel and commercially viable process } \\
\text { which has been developed for the preparation of Azilsartan, a pro-drug of Azilsartan } \\
\text { medoxomil, an angiotensin II receptor blocker. The present work also provides a primary } \\
\text { account of the synthesis and characterization of the novel intermediates }(6,7 \mathbf{8} \mathbf{1 0}) \text { of } \\
\text { Azilsartan, with their spectral data. }\end{array}$} \\
\hline $\begin{array}{l}\text { Keywords: } \\
\text { Azilsartan, } \\
\text { novel intermediates, } \\
\text { synthesis and characterization. }\end{array}$ & \\
\hline
\end{tabular}
\end{abstract}

\section{INTRODUCTION}

Azilsartan medoxomil is an AT1-subtype angiotensin II receptor blocker (ARB), wherein, angiotensin II is formed from angiotensin $\mathrm{I}$ in a reaction catalyzed by the angiotensin converting enzyme. Angiotensin II is the principal pressor agent of the rennin-angiotensin system [1,2], with effects that include vasoconstriction, stimulation of synthesis and release of aldosterone, cardiac stimulation, and renal reabsorption of sodium. Azilsartan medoxomil blocks the vasoconstrictor and aldosterone-secreting effects of angiotensin II by selectively blocking the binding of angiotensin II to the AT1 receptor in many tissues, such as the vascular smooth muscle and the adrenal gland. Azilsartan medoxomil, a pro-drug form of azilsartan 2, was approved in 2011, and is used for the treatment of hypertension. It is marketed by Takeda, under the brand name of Edarbi ${ }^{\circledR}$. Azilsartan medoxomil 1 is chemically known as (5-methyl-2-oxo1,3-dioxol-4-yl)methyl 2-ethoxy-1- $\left\{\left[2^{\prime}-(5\right.\right.$-oxo-4,5-dihydro-1,2,4-oxadiazol-3-yl)biphenyl-4yl]methyl $\}-1 \mathrm{H}-$ benzimidazole-7-carboxylate. Azilsartan $\mathbf{2}$ is chemically known as 2-ethoxy-1-\{[2'-(5-oxo-4,5-dihydro-1,2,4-oxadiazol-3-yl) biphenyl-4yl]methyl $\}-1 \mathrm{H}-$ benzimidazole-7-carboxylic acid.

\footnotetext{
* Corresponding author

e-mail: srinivasgaraga@yahoo.com

tel.: +91 8455223757 ; fax: +91 845523044873
}

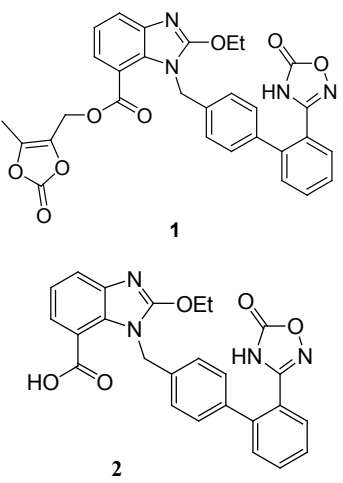

Figure 1. Structures of Azilsartan medoxomil 1 and Azilsartan 2

Several references [3-13] have described the synthesis of azilsartan, but very few references [14] have been found for the synthesis of azilsartan from 4'-(bromomethyl) -1,1'-biphenyl-1,2,4-oxadiazol-5(2H)-one 11.

The synthetic pathway, as described in the previous literature [11], is given in Scheme 1. In the first step, methyl 2-tert-butoxycarbonyl amino-3-nitrobenzoate 3, when condensed with 2-(4-bromomethyl phenyl)benzonitrile 4, gives compound $\mathbf{5}$. The subsequent de-protection of compound $\mathbf{5}$ with trifluoroacetic acid, gives compound $\mathbf{6}$. Reduction of compound $\mathbf{6}$ with stannous chloride, gives compound 7. Compound 7 is then cyclized with tetraethyl orthocarbonate, giving BEC methyl ester 8 . BEC methyl ester is 
subsequently treated with hydroxylamine hydrochloride, giving amidoxime 9. Compound 9 is treated with ethyl chloroformate resulting in an intermediate, which is further cyclized to provide azilsartan methyl ester 10 in xylene. Finally, azilsartan methyl ester 10 is hydrolyzed with sodium hydroxide, giving azilsartan 2 .
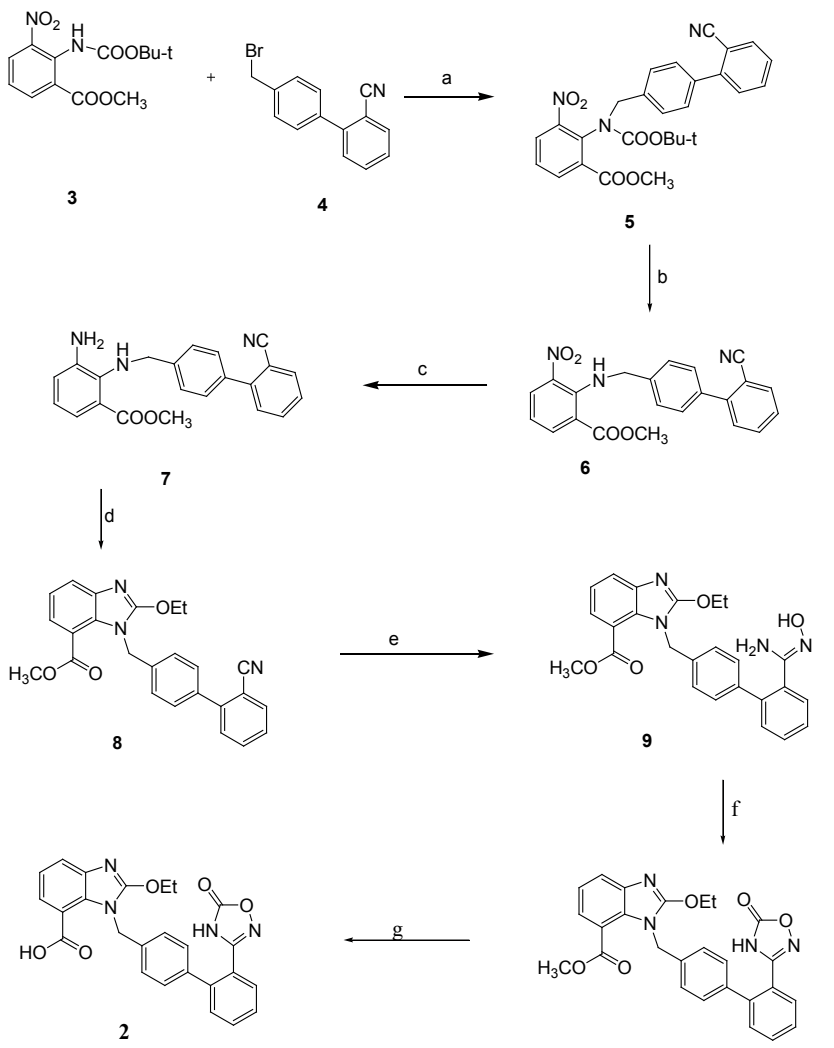

10

Scheme 1. Reported synthetic route for Azilsartan

Reagents and conditions: (a) $\mathrm{K}_{2} \mathrm{CO}_{3}$, acetonitrile, $80-85^{\circ} \mathrm{C}$ (b) TFA, DCM, $20-25^{\circ} \mathrm{C}, 66 \%$ (c) $\mathrm{SnCl}_{2}, \mathrm{THF}, 60-65^{\circ} \mathrm{C}$, $80 \%$ (d) tetraethyl orthocarbonate, acetic acid, methanol, $20-25^{\circ} \mathrm{C}, 73 \%$ (e) $\mathrm{NH} 2 \mathrm{OH}, \mathrm{NaOMe}$, DMSO, 55\% (f) ethylchloroformate, TEA,DCM, Xylene, $110^{\circ} \mathrm{C}, 50 \%$ (g) $\mathrm{NaOH}$, $\mathrm{H}_{2} \mathrm{O}, 40-45^{\circ} \mathrm{C}, 95 \%$.

The main draw back of the aforementioned process, is its low yields $(55 \%$ and $50 \%)$ at the amidoxime production stage, and the cyclization steps necessarily undertaken due to the formation of impurities. To overcome these low yields problems, we have developed an alternative synthesis. This is from 4'-(bromomethyl)-1,1'-biphenyl-1,2,4oxadiazol-5(2H)-one 11. This process is mainly noted for both generating high yields and incorporating simple work up procedures.

The present invention relates to the synthesis of azilsartan by using commercially available starting materials such as methyl 2-tert-butoxycarbonyl amino-3-nitrobenzoate 3 and 4'-(bromomethyl) -1,1'-biphenyl-1,2,4-oxadiazol-5(2H)-one 11. Within this unconventional process, compounds 13, 14 and $\mathbf{1 5}$ are novel, and, hence, we are reporting their synthesis and characterization for the first time, along with their spectral data. The main goal of this work was to develop a safe, economic and non-infringing process for the synthesis of Azilsartan 2.

\section{RESULTS AND DISCUSSION}

In our approach (as shown in Scheme 2), we bring about the condensation of compound 3 with $\mathbf{1 1}$, in the presence of potassium carbonate, giving compound 12. Compound 12 is then de-protected with trifluoroacetic acid, yielding a corresponding nitro compound $\mathbf{1 3}$. Compound $\mathbf{1 3}$ is subsequently reduced with stannous chloride, giving a corresponding amino compound 14. Compound 14 is then cyclized with tetraethyl orthocarbonate, generating azilsartan methyl ester 10. Finally, azilsartan methyl ester $\mathbf{1 0}$ is hydrolysed by using sodium hydroxide, resulting in the targeted molecule azilsartan 2 .

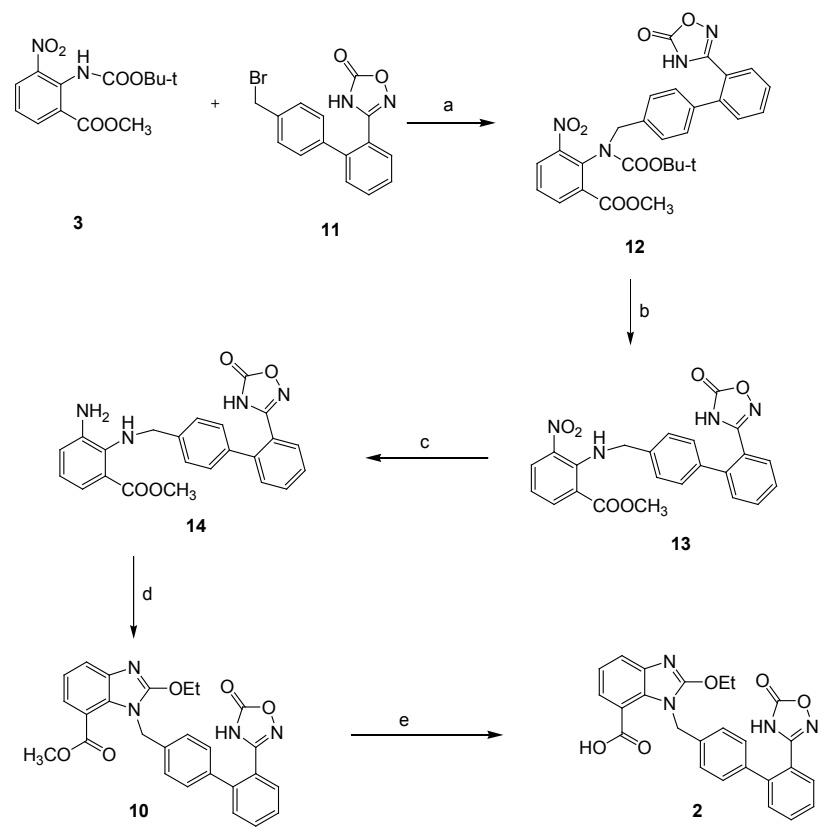

Scheme 2. Novel synthetic route for the synthesis of Azilsartan 2. Reagents and conditions: (a) $\mathrm{K} 2 \mathrm{CO} 3$, acetonitrile, $80-85^{\circ} \mathrm{C}$, (b) TFA, DCM, $20-25^{\circ} \mathrm{C}, 66 \%$ (c) $\mathrm{SnCl} 2$, THF, $60-65^{\circ} \mathrm{C}, 80 \%$ (d) tetraethyl orthocarbonate, acetic acid, methanol, $20-25^{\circ} \mathrm{C}, 73 \%$ (e) $\mathrm{NaOH}, \mathrm{H} 2 \mathrm{O}, 40-45^{\circ} \mathrm{C}, 95 \%$
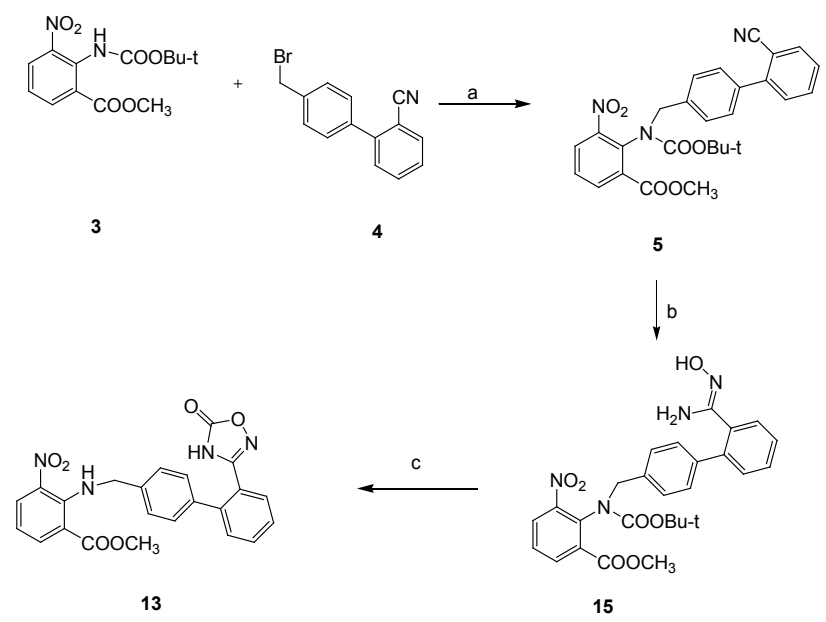

Scheme 3. Novel synthetic route for the synthesis of compound 13. Reagents and conditions: (a) $\mathrm{K}_{2} \mathrm{CO}_{3}$, acetonitrile, $80-85^{\circ} \mathrm{C}$ (b) $\mathrm{NH}_{2} \mathrm{OH} . \mathrm{HCl}, \mathrm{NaHCO}_{3}, 80-85^{\circ} \mathrm{C}, 75 \%$ (c) CDI, DBU, THF, $20-25^{\circ} \mathrm{C}, 94 \%$ 
Our unconventional way towards generating azilsar$\tan 2$ (as shown in scheme 3 ), comes about by condensing 13 with 2-(4-bromomethyl phenyl)benzonitrile 4, yielding compound $\mathbf{5}$. Compound $\mathbf{5}$ is then treated with hydroxylamine hydrochloride in the presence of sodium bicarbonate giving 15. Cyclization of compound $\mathbf{1 5}$ with carbonyldiimidazole, subsequently generates nitro compound 13. Of note: during the work-up process of cyclization of 15, we used aqueous sodium bisulfite washing to remove the imidazole by-product. But surprisingly, in so doing, we observed the de-protection of the t-butyl group by way of this sodium bisulfite washing, and, discovered that we could therefore directly obtain nitro compound $\mathbf{1 3}$.

The aforementioned compounds $\mathbf{3}$ and $\mathbf{4}$ are known in the literature [14], and we prepared these compounds by using known literature methods. Compound $\mathbf{5}$ is also known in the literature.[15,16], thus we prepared this compound by using known literature methods.

Synthesis of the Amidoxime intermediate (compound 15)

In this sub-process, compound $\mathbf{5}$ was treated with hydroxylamine hydrochloride in the presence of a base at a higher temperature, resulting in an amidoxime intermediate 15. To develop a suitable amidoxime reaction, we tried different bases such as sodium methoxide, triethylamine and sodium bicarbonate. Of all these bases, the best results were obtained by employing sodium bicarbonate. The mass spectrum of compound $\mathbf{1 5}$ showed a molecular ion at $\mathrm{m} / \mathrm{z} 521.2039$, while the NMR spectrum revealed a singlet at $\delta 5.47, \delta 9.19$, corresponding to the $\mathrm{NH}_{2}$ and $\mathrm{OH}$ protons in the amidoxime intermediate 15. In addition, the infrared (IR) spectrum showed absorptions at 3499, 3398 and 3196. These correspond to $-\mathrm{NH}_{2}$ and $-\mathrm{OH}$ stretching, respectively, confirming the assigned structure.

\section{Synthesis of Nitro compound 13}

Compound 13 was prepared from compound 15 by using a cyclizing agent. To develop this cyclization reaction, we tried different reagents. Among these were carbonyldiimidazole, triphosgene, diphenyl carbonate, disuccinimidyl carbonate, diethyl carbonate and dimethyl carbonate. We found that the best results were obtained by using carbonyldiimidazole. The mass spectrum of compound $\mathbf{1 3}$ showed a molecular ion at $\mathrm{m} / \mathrm{z} 447.1313$, while the NMR spectrum revealed a broad singlet at $\delta 12.4$, corresponding to the $\mathrm{NH}$ proton in an oxadiazole ring. The absence of $\mathrm{NH}_{2}$ and $\mathrm{OH}$ protons also confirmed the structure. Moreover, the infrared (IR) spectrum showed absorptions at 3438 and 1537, corresponding to -NH and -NO stretching, respectively, and confirming the assigned structure.

\section{Synthesis of Amino compound 14}

Compound 14 was prepared by the reduction of compound 13. So as to develop this reduction, we tried different reducing agents. Among these being stannous chloride, ferric chloride and Raney nickel. In this work, the best results were obtained by using stannous chloride. The mass spectrum of compound $\mathbf{1 4}$ showed a molecular ion at $\mathrm{m} / \mathrm{z} 417.1558$, and the NMR spectrum revealed broad singlets at $\delta 4.92$ and 6.17 , which correspond to the $\mathrm{NH}_{2}$ and $\mathrm{NH}$ protons in amino compound $\mathbf{1 4}$. What is more, the Infrared (IR) spectrum showed absorptions at 3499. This corresponds to $-\mathrm{NH}_{2}$, while the absence of $\mathrm{N}-\mathrm{O}$ stretching at 1537 also confirms the assigned structure.

\section{Synthesis of Azilsartan methyl ester 10}

Compound 10 was prepared from compound 14, by cyclizing it with tetraethyl orthocarbonate. The mass spectrum of compound $\mathbf{1 0}$ revealed a molecular ion at $\mathrm{m} / \mathrm{z}$ 471.1638, and the NMR spectrum showed a triplet at $\delta 1.36$ and a quartet at $\delta 4.606$, corresponding to the $\mathrm{CH}_{3}$ and $\mathrm{CH}_{2}$ protons.

All these reported reaction procedures are very simple to undertake, and they provided excellent yields of the products. Thus, this process is economic and useful for the commercial manufacture of Azilsartan 2.

\section{CONCLUSION}

To the extension of our previous work [17], we have developed a non-infringing process for the synthesis of Azilsartan 2, beginning from methyl 2-tert-butoxycarbonyl amino-3-nitrobenzoate 3 and 4'-(bromomethyl)-1,1'-biphenyl-1,2,4-oxadiazol-5(2H)-one 11. The present work also describes the synthesis and characterization of novel intermediates of Azilsartan, along with their spectral data.

\section{EXPERIMENTAL}

The solvents and reagents were obtained from commercial sources and used without purification. The IR spectra $\left(\vartheta_{\max }, \mathrm{cm}^{-1}\right)$ were recorded in solid state $\mathrm{KBr}$ dispersion, using a Perkin Elmer FT-IR spectrometer. The ${ }^{1} \mathrm{H}-\mathrm{NMR}$ and ${ }^{13} \mathrm{C}$-NMR spectra were recorded on a Bruker-Avance $300 \mathrm{MHz}, 500 \mathrm{MHz}$ and $125 \mathrm{MHz}$ spectrometer. The chemical shifts were reported in $\delta$ ppm relative to TMS. The mass spectra were recorded on an API 2000 Perkin Elmer PE-Sciex mass spectrometer. In addition, the reactions were monitored by Thin-layer chromatography (TLC), while melting points were determined on a polman melting point apparatus (Model No MP96), by way of the open capillary method, and are uncorrected.

\section{Methyl 3-nitro-2-[[4-[2-(5-oxo-4H-1,2,4-oxadiazol-3-yl) phenyl]phenyl] methyl amino]benzoate (13)}

To a suspension of compound 3 (100 g, $337.8 \mathrm{mmol})$ and 11 (110 g, $334.4 \mathrm{mmol})$ in acetonitrile $(1000 \mathrm{~mL})$, we added potassium carbonate $(140 \mathrm{~g}, 1011.3 \mathrm{mmol})$ at $20-25^{\circ} \mathrm{C}$. The reaction mixture was stirred for $12 \mathrm{~h}$ at $80-85^{\circ} \mathrm{C}$, then the resulting salts were removed by filtration, and the filtrate was concentrated under reduced pressure, resulting in a residue which contains compound 12 . The residue was subsequently dissolved in dichloromethane $(100 \mathrm{~mL})$, while trifluoroacetic acid $(37.6 \mathrm{~g}, 329.6 \mathrm{mmol})$ was added at $20-25^{\circ} \mathrm{C}$. The reaction mixture was then stirred for $4 \mathrm{~h}$, at room temperature. Subsequently, water $(500 \mathrm{~mL})$ was added to the reaction mass, and the PH was adjusted to 6 with saturated sodium bicarbonate solution. Following this, the organic layer was separated and concentrated under reduced pressure, resulting in residue $13(102 \mathrm{~g}, 66 \%)$. HRMS for $\mathrm{C}_{23} \mathrm{H}_{18} \mathrm{~N}_{4} \mathrm{O}{ }_{6}(\mathrm{M}+\mathrm{H})^{+}$: 
calculated: 447.1260, found: 447.1313. 1H-NMR (DMSO) d (ppm): 12.36 (bs, 1H, NH), 8.11 (m, 1H, Ar), 8.03 (m, 1H, Ar), 7.6 (m, 4H,Ar), 7.57 (m, 1H, Ar), 7.47 (m, 1H, Ar), 7.18 (m, 4H, Ar), 4.61 (d, J = 15 Hz, 1H, N-CH -Ar), 4.54 (d, J = $\left.14.5 \mathrm{~Hz}, 1 \mathrm{H}, \mathrm{N}-\mathrm{CH}_{2}-\mathrm{Ar}\right), 3.6\left(\mathrm{~s}, 3 \mathrm{H}, \mathrm{COOCH}_{3}\right) .{ }^{13} \mathrm{C}-\mathrm{NMR}$ (DMSO) d (ppm): 164.51, 159.62, 158.31, 153.13, 148.17, $141.01,138.21,135.49,134.89,133.67,132.06,131.65$, $130.61,129.47,129.09,128.97,128.05,127.77,122.34$, 80.12, 67.31, 63.35, 52.65, 40.09. IR (KBr pellet): 3438, 2978, 1708, 1603, 1577, 1295, $1129 \mathrm{Cm}^{-1}$.

Methyl 3-amino-2-[[4-[2-(5-oxo-4H-1,2,4-oxadiazol-3-yl) phenyl]phenyl] methyl amino]benzoate (14)

To a solution of compound $\mathbf{1 3}(100 \mathrm{~g}, 224.2 \mathrm{mmol})$ in tetrahydrofuran $(1000 \mathrm{~mL})$, we added stannous chloride $(101.1 \mathrm{~g}$, $448.4 \mathrm{mmol})$ at $25-30^{\circ} \mathrm{C}$. The reaction mixture was then stirred at $60-65^{\circ} \mathrm{C}$, for $6 \mathrm{~h}$. Subsequently, we diluted the reaction mixture with water $(500 \mathrm{~mL})$ and ethylacetate $(1000$ $\mathrm{mL}$ ). We followed this up by adjusting the $\mathrm{pH}$ of the reaction mixture to 12 , with $20 \% \mathrm{w} / \mathrm{w}$ sodium hydroxide solution, and the organic layer was separated. This organic layer was washed with saturated sodium bicarbonate solution (1000 $\mathrm{mL}$ ) and saturated sodium chloride solution $(1000 \mathrm{~mL}) . \mathrm{We}$ then concentrated the organic layer under reduced pressure. This yielded a residue, which, when crystallized with diisopropyl ether, resulted in a pale yellow colored compound $\mathbf{1 4}$ (75 g, 80\%). HRMS for $\mathrm{C}_{23} \mathrm{H}_{20} \mathrm{~N}_{4} \mathrm{O}_{4}(\mathrm{M}+\mathrm{H})^{+}$: calculated: 417.1518, found: 417.1558. 1H-NMR (DMSO) d (ppm): 7.65 (m, 2H, Ar), 7.51 (m, 2H, Ar), 7.37 (m, 2H, Ar), 7.29 (m, 1H, Ar), 7.188 (m, 1H, Ar), 7.04 (m, 1H, Ar), 6.92 (m, 1H, Ar), 6.78 (m, 1H, Ar), 6.17 (bs, 1H, NH), 4.92 (bs, 2H, NH $), 4.12$ (s, 2H, N-CH $-\mathrm{Ar}), 3.775$ (s, 3H, $\left.\mathrm{OCH}_{3}\right) .{ }^{13} \mathrm{C}-\mathrm{NMR}$ (DMSO) d (ppm): 166.40, 162.78, 160.91, 154.59, 145.76, 142.56, 140.89 , 139.446, 137.99, 137.63, 137.23, 131.14, 130.90, $130.51,129.23,128.95,127.99,127.65,127.12,125.59$, 124.26, 121.81, 120.46, 119.13, 119.06, 118.55, 117.95, 78.69, 67.30, 51.81, 48.85, 40.00. IR (KBr pellet): 3514, 3407, 3268, $2985,1718,1634,1612,1547,1284,1257,1133 \mathrm{Cm}^{-1}$.

Methyl2-ethoxy-3-[[4-[2-(5-oxo-4H-1,2,4-oxadiazol-3-yl) phenyl]phenyl] methyl]benzimidazole-4-carboxylate (Azilsartan methyl ester 10)

To a mixture of compound 14 (100 g, $240 \mathrm{mmol})$ in tetraethyl orthocarbonate $(92.3 \mathrm{~g}, 480 \mathrm{mmol})$, we added acetic acid $(28.8 \mathrm{~g}, 480 \mathrm{mmol})$ at $25-30^{\circ} \mathrm{C}$. The reaction mass was then heated to reflux for $3 \mathrm{~h}$. Subsequently, the reaction mass was diluted with methanol $(300 \mathrm{~mL})$, water $(400 \mathrm{~mL})$ and $30 \%$ sodium hydroxide solution $(30 \mathrm{~mL})$. The reaction mass was then stirred at $25-30^{\circ} \mathrm{C}$, for $2 \mathrm{~h}$, and the $\mathrm{PH}$ neutralized to 7 . We followed this up by cooling the solution to $5-10^{\circ} \mathrm{C}$, and filtering the precipitated product, yielding a white colored compound $10(82 \mathrm{~g}, 73 \%)$. HPLC purity: 99.49\%. HRMS for $\mathrm{C}_{26} \mathrm{H}_{22} \mathrm{~N}_{4} \mathrm{O}_{5}(\mathrm{M}+\mathrm{H})^{+}$: calculated: 471.1624, found: 471.1638. 1H-NMR (DMSO) d (ppm): 12.383 (bs, 1H, NH), 7.7-7.63 (m, 3H, Ar), 7.56 (m, 1H, Ar), 7.47 (m, 2H, Ar), 7.246 (d, J = 1.5 Hz, 2H, Ar), 7.196 (t, J $=8 \mathrm{~Hz}, 1 \mathrm{H}, \mathrm{Ar}), 7.0(\mathrm{~d}, \mathrm{~J}=8.5 \mathrm{~Hz}, 2 \mathrm{H}, \mathrm{Ar}) 5.529(\mathrm{~s}, 2 \mathrm{H}$, $\mathrm{N}-\mathrm{CH}_{2}-\mathrm{Ar}$ ), 4.628 (q, $2 \mathrm{H}, \mathrm{OCH}_{2} \mathrm{CH}_{3}$ ), 3.68 (s, 3H, $\mathrm{OCH}_{3}$ ), $1.38\left(\mathrm{t}, \mathrm{J}=7.5 \mathrm{~Hz}, 3 \mathrm{H}, \mathrm{OCH}_{2} \mathrm{CH}_{3}\right)$. IR (KBr pellet):2983, $1779,1720,1609,1547,1281,1133 \mathrm{Cm}^{-1}$. 2-ethoxy-1-\{[2'-(5-oxo-4,5-dihydro-1,2,4-oxadiazol-3-yl) biphenyl-4yl]methyl\}-1H-benzimidazole-7-carboxylicacid (Azilsartan 2)

Compound 10 (100 g, $212.7 \mathrm{mmol})$ was added to aqueous sodium hydroxide $(25.5 \mathrm{~g}$ in $200 \mathrm{~mL}$ of water, $638.2 \mathrm{mmol}$ ) at room temperature and mixture was stirred for $6 \mathrm{~h}$ at $40-45^{\circ} \mathrm{C}$. Then the reaction mixture was acidified with aqueous hydrochloric acid to $4 \mathrm{pH}$. The precipitated product was filtered and wash with water results a white compound 2 (92 g, 95\%) mp: $210-213^{\circ} \mathrm{C}$. HPLC purity: 99.48\%. HRMS for $\mathrm{C}_{25} \mathrm{H}_{20} \mathrm{~N}_{4} \mathrm{O}_{5}(\mathrm{M}+\mathrm{H})^{+}$Calcd: 457.1467, found: 457.1479. ${ }^{1} \mathrm{H}-\mathrm{NMR}$ (DMSO) $\delta$ (ppm): 13.15 (bs, $1 \mathrm{H}$, $\mathrm{NH}), 12.4$ (bs, 1H, OH), 7.68-7.63 (m, 3H, Ar), 7.56-7.55 (m, 2H, Ar), 7.52-7.46 (m, 1H, Ar), 7.245 (d, J=8.3 Hz, 2H, Ar), 7.197 (t, 1H, Ar), 7.05 (d, J=8.3 Hz, 2H, Ar) 5.67 (s, 2H, $\mathrm{N}-\mathrm{CH} 2-\mathrm{Ar}$ ), 4.578 (q, 2H, OCH2CH3), 1.38 (t, J=7.1 Hz, $3 \mathrm{H}, \mathrm{OCH}_{2} \mathrm{CH}_{3}$ ). IR (KBr pellet): 2989, 1774, 1733, 1613, 1552, 1286, $1145 \mathrm{Cm}-1$.

\section{Methyl 2-[tert-butoxycarbonyl[[4-[2-( $N$ '-hydroxycar- bamimidoyl) phenyl] phenyl] methyl]amino] 3-nitro- benzoate 15}

To a suspension of hydroxylamine hydrochloride $(84.55 \mathrm{~g}$, $1216.5 \mathrm{mmol}$ ) and sodium bicarbonate $(112.4 \mathrm{~g}, 1338 \mathrm{mmol})$ in DMSO (500 mL), we added compound 5 (100 g, 205.3 $\mathrm{mmol})$ at $45-50^{\circ} \mathrm{C}$. The reaction mixture was then stirred at $80-85^{\circ} \mathrm{C}$, for $24 \mathrm{~h}$. We followed this up by pouring the mixture into water $(2000 \mathrm{~mL})$ and stirring this solution for $1 \mathrm{~h}$. The resulting product was then filtered and purified with ethanol, yielding a white compound 15 (80 g, $75 \%$ ). HRMS for $\mathrm{C}_{27} \mathrm{H}_{28} \mathrm{~N}_{4} \mathrm{O}_{7}(\mathrm{M}+\mathrm{H})^{+}$: calculated: 521.1992, found: 521.2039. ${ }^{1} \mathrm{H}-\mathrm{NMR}$ (DMSO) $\delta(\mathrm{ppm}): 9.197(\mathrm{~s}$, 1H, OH), 8.159 (m, 1H, Ar), 8.142 (m, 1H, Ar), 7.656 (m, 1H, Ar), 7.447 (m, 1H, Ar), 7.41 (m, 2H, Ar), 7.308 (m, $3 \mathrm{H}, \mathrm{Ar}), 7.087$ (m, 2H, Ar), 5.474 (bs, 2H, NH $), 4.633$ (dd, $\left.\mathrm{J}=14,14.5 \mathrm{~Hz}, 2 \mathrm{H}, \mathrm{N}-\mathrm{CH}_{2}-\mathrm{Ar}\right), 3.61\left(\mathrm{~s}, 3 \mathrm{H}, \mathrm{OCH}_{3}\right), 1.479$ (s, 9H, t-Bu). ${ }^{13} \mathrm{C}-\mathrm{NMR}$ (DMSO) $\delta$ (ppm): 164.53, 153.52, $153.23,152.10,148.63,140.04,139.96,135.00,134.73$, $133.15,132.27,131.85,130.06,129.94,128.94,128.39$, $126.95,52.73,39.66,39.44,27.95,27.55$. IR (KBr pellet): 3499, 3398, 3196, 2976, 1698, 1647, 1600, 1536, 1288, $1270,1124 \mathrm{Cm}^{-1}$.

Methyl 3-nitro-2-[[4-[2-(5-oxo-4H-1,2,4-oxadiazol-3-yl) phenyl]phenyl]methyl amino]benzoate (13) from 15

To a solution of compound $\mathbf{1 5}$ (100 g, $192.3 \mathrm{mmol})$ in tetrahydrofuran $(1000 \mathrm{~mL})$, we added carbonyldiimidazole (51.5 g, $317.3 \mathrm{mmol})$ and DBU (44.5 g, $292.3 \mathrm{mmol})$ at $20-25^{\circ} \mathrm{C}$. We then stirred the reaction mixture for $2 \mathrm{~h}$, at $20-25^{\circ} \mathrm{C}$. Subsequently, we diluted the reaction mixture with ethyl acetate $(1000 \mathrm{~mL})$ and washed it with saturated sodium bisulfite solution $(1000 \mathrm{~mL})$, followed by saturated sodium chloride solution $(1000 \mathrm{~mL})$. The organic layer was then separated and concentrated under reduced pressure at $35-40^{\circ} \mathrm{C}$ to obtain a residue 13 (80 g, 94\%). HRMS for $\mathrm{C}_{23} \mathrm{H}_{18} \mathrm{~N}_{4} \mathrm{O}_{6}$ $(\mathrm{M}+\mathrm{H})+$ : calculated: 447.1260 , found: $447.1313 .{ }^{1} \mathrm{H}-\mathrm{NMR}$ (DMSO) $\delta$ (ppm): 12.36 (bs, 1H, NH), 8.11 (m, 1H, Ar), 8.03 (m, 1H, Ar), 7.6 (m, 4H,Ar), 7.57 (m, 1H, Ar), 7.47 (m, 1H, Ar), 7.18 (m, 4H, Ar), 4.61 (d, 1H, N-CH $-\mathrm{Ar}$ ), 4.54 (d, 1H, N-CH $-\mathrm{Ar}), 3.6$ (s, 3H, $\left.\mathrm{COOCH}_{3}\right) .{ }^{13} \mathrm{C}-\mathrm{NMR}$ 
(DMSO) $\delta$ (ppm): 164.51, 159.62, 158.31, 153.13, 148.17, $141.01,138.21,135.49,134.89,133.67,132.06,131.65$, $130.61,129.47,129.09,128.97,128.05,127.77,122.34$, 80.12, 67.31, 63.35, 52.65, 40.09. IR (KBr pellet): 3438 , 2978, 1708, 1603, 1577, 1295, $1129 \mathrm{Cm}^{-1}$.

\section{ACKNOWLEDGMENTS}

The authors gratefully acknowledge the management of Aurobindo pharma limited for allowing us to carry out this research work.

\section{ABBREVIATIONS}

DMSO, dimethyl sulfoxide; DMAc, N,N-dimethylacetamide; DMF, N,N-dimethylformamide; DSC, disuccinimidyl carbonate; TFA, trifluoroacetic acid; DIBOC, Di-tert-butyl dicarbonate; DMC, dimethyl carbonate; DEC, diethyl carbonate; DPC, diphenyl carbonate; CDI, carbonyldiimidazole; DBU, 1,8-diazabicyclo 5.4.0 undec-7-ene.

\section{REFERENCES}

1. Aulakh G.K., Sodhi R. K., Singh M.: An update on non-peptide angiotensin receptor antagonists and related RAAS modulators. J. Life Sci. 2007, 81, 615-639.

2. Miura S., Karnik S. S., Saku K.: Ability of the new AT1 receptor blocker azilsartan to block angiotensin II-induced AT1 receptor activation after wash-out. J Renin Angiotensin Aldosterone Syst. 2011, 12, 1-7.

3. Naka T. K., Inada. Y.: Compound which is an angiotensin antagonist. U.S.Patent No.5,243,054.
4. Kuroita T., Sakamoto H., Ojima, M.: Benzimidazole derivative and use thereof. U.S.Patent No.7,157,584.

5. Bansal D. et al.: An improved process for the preparation of azilsartan medoxomil. WO/2012/107814, 2012.

6. Radl S., Stach J.: A method of preparing 2-ethoxy-1-((2'-(5-oxo-4,5dihydro-1,2,4-oxadiazol-3-yl)biphenyl-4-yl)methyl)-1H-benzo[d] imidazole-7-carboxylates and conversion thereof to azilsartan. WO/2012/139535. 2012.

7. Jo N. et al.: A manufacturing method for azilsartan $\mathrm{WO} / 2012$ / 157980, 2012.

8. Kshirsagar P.B. et al.: The process for the preparation of azilsartan medoxomil, WO/2013/042066, 2013.

9. Kohara Y. et al.: A new class of angiotensin II receptor antagonists with a novel acidic bioisostere. Bioorg. Med. Chem. Lett. 1995, 5, 1903-1908.

10. Kohara Y. et al.: Synthesis and Angiotensin II Receptor Antagonistic Activities of Benzimidazole Derivatives Bearing Acidic Heterocycles as Novel Tetrazole Bioisosteres. J. Med. Chem. 1996, 39, 5228-5235.

11. Kubo K. et al.: Nonpeptide angiotensin II receptor antagonists. Synthesis and biological activity of benzimidazolecarboxylic acids. J. Med. Chem. 1993, 36, 2182-2195.

12. Stanislav R., Josef C., Jan S., Zuzana G.: Improved Process for Azilsartan Medoxomil: A New Angiotensin Receptor Blocker. Org. Process Res. Dev. 2013, 17, 77-86.

13. Raghava Reddy A.V. et al.: A novel process for the preparation of Azilsartan medoxomil. Indian patent App. No. 4226/CHE/2012A.

14. Dubey S.K. et al.: Indian patent Appl. No. IN2011DE01901 A 20131004.

15. Aldo S., Renato C.: Preparation of olmesartan medoxomil. U.S.Pat. No.6,111,114

16. Hideo H., Tadashi H., Masaayasu K.: Production method of aminobenzene compound. U.S.Pat. No. 6,177,587 B1

17. Srinivas G. et al.: Commercial Synthesis of Azilsartan Kamedoxomil: An Angiotensin II Receptor Blocker. Org. Process Res. Dev., 2015, 19 (4), 514-519. 